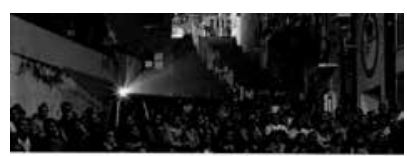

IRALCINE

ANTROPOLOGIA DELOS PUBBLICOS LA CIUDAD Y LAS PANTALLAS

Ana Rosas Mantecón

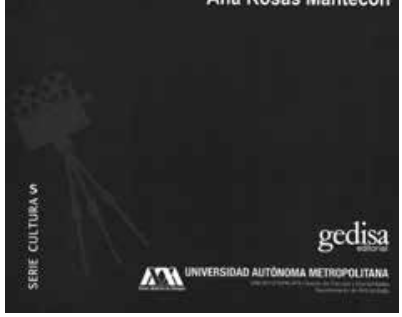

Anthropology Goes to the Cinema

ANTONIO ZIRIÓN PÉREZ

Departamento de Antropología, Universidad Autónoma MetropolitanaIztapalapa, Ciudad de México, México zirion@gmail.com

Desacatos 56 , enero-abril 2018, pp. 208-212
- Ir al cine. Antropología de los públicos,

la ciudad y las pantallas

Ana Rosas MANTECón, 2017

Gedisa/Universidad Autónoma

Metropolitana-Iztapalapa, México

\section{La antropología va al cine}

\author{
ANTONIO ZIRIÓN PÉREZ
}

sta reseña no puede más que comenzar celebrando el lanzamiento de Ir al cine. Antropología de los públicos, la ciudad y las pantallas de Ana Rosas Mantecón, un libro tan esperado e importante que con seguridad se convertirá pronto en un clásico, en una referencia obligada para cualquier estudio sobre el cine en nuestro país, en particular, en la Ciudad de México, tanto de su pasado como del presente o con miras al futuro.

Quisiera mencionar algunas razones por las que escribo esta reseña. Primero, para manifestar mi orgullo hacia el Departamento de Antropología de la Universidad Autónoma Metropolitana-Iztapalapa, en el que Ana Rosas desarrolló esta investigación. Ahí se pueden llevar a cabo investigaciones de largo aliento, como ésta, con plena libertad, con apoyo institucional y con la retroalimentación de grandes colegas. Ahí se practica una antropología de vanguardia, que estudia las culturas contemporáneas con nuevos enfoques. Como investigador y programador de cine, estoy muy interesado en la formación de públicos y en la posibilidad de transformación social a partir del cine, por medio de nuevas redes y circuitos alternativos de difusión y exhibición, que ofrecen otras maneras de vivir el cine, algo de lo que Rosas Mantecón habla en el último capítulo de su libro. Por último, como cinéfilo, como público 
amante del cine, puedo asegurar que este libro nos ayuda a entendernos un poco mejor y a descubrir por qué nos gusta tanto y por qué es importante ir al cine.

En este sentido, y a propósito de la autora, puede decirse que se trata de un libro un tanto autobiográfico o autorreflexivo, que parte de una especie de autoetnografía. Porque Ana Rosas es una auténtica cinéfila, público asiduo, espectadora apasionada; siempre está al día de la cartelera y la programación de festivales; todo el tiempo recomienda películas y se toma muy en serio las recomendaciones de los demás. Ella está íntimamente implicada en su objeto de estudio y lo asume de manera muy coherente y honesta. Después de todo, la elección de un problema de investigación dice tanto de la realidad que estudia como de los intereses y motivos del propio investigador.

Este libro es tan completo que su lectura enriquece como la de varios libros a la vez. A lo largo de los capítulos seguimos una progresión argumentativa de varios temas, que al final resultan entretejidos con un hilo conductor muy fino. Cada capítulo, como las tomas que componen una escena, despliega una variedad de encuadres y enfoques. La toma 1 sienta las bases teóricas y conceptuales para el estudio del consumo cultural y la investigación sobre públicos, trata nociones centrales, como esfera pública, campo cultural, industrias creativas, etc. La toma 2 reconstruye el surgimiento y los primeros desarrollos del fenómeno cinematográfico en nuestro país, desde la llegada del cinematógrafo de los Lumière, y relata cómo surgieron nuevas formas de sociabilidad, de estar juntos en la ciudad por medio del espectáculo cinematográfico. La toma 3 se concentra en la Época de Oro del cine, que es también la época dorada de la Ciudad de México, y explica cómo a partir del papel rector del Estado hubo un desarrollo considerable en términos de infraestructura urbana e industria del cine, además de un crecimiento y la diversificación exponenciales de los públicos de cine, lo que señala una correspondencia inequívoca entre ir al cine y habitar la ciudad; entre ser público de cine y ser ciudadano. La toma 4 analiza el fin de esa era y el advenimiento de un periodo de crisis, desde finales la década de 1960 y hasta mediados de la de 1990, en cuanto a la cantidad y calidad de la producción de cine mexicano, y la consecuente caída en picada de su disfrute por parte de los públicos mexicanos, cada vez más reducidos. La toma 5 estudia el panorama actual y los escenarios emergentes, en medio de un aparente resurgimiento de la exhibición y un repunte de los públicos, impulsados por los desarrollos tecnológicos de la llamada convergencia digital. Las conclusiones llevan a cabo un ejercicio de imaginación de futuros posibles a partir de múltiples condiciones que ya están a la vista, pero que apenas comenzamos a entender.

Como en una buena película, estos episodios trazan una curva dramática perfectamente estructurada. Primero se establece el tema y el género del filme, el desarrollo de los personajes, las relaciones entre los elementos y el contexto. Luego se presenta el conflicto, que de manera paulatina se incrementa hasta llegar a una crisis. Por último, se alcanza una resolución o desenlace, para terminar con un epílogo, una suerte de puntos suspensivos o final abierto, para que el espectador - o lector- se involucre y participe como actor, director, colaborador o investigador de esta trama.

Ir al cine puede leerse de principio a fin, si uno tiene la fortuna de contar con el tiempo para navegar con calma por sus páginas, una a una; pero también es un libro que permite consultarse por partes, en desorden, según las preguntas que tengamos o queramos hacerle. Sin duda, siempre encontraremos en él más de lo que buscamos, pues ofrece una mina de referencias, ideas, datos, anécdotas, análisis, opiniones y posiciones en torno al cine en nuestro contexto nacional.

Esta obra contiene los prolegómenos para varias disciplinas posibles — sociología del cine, psicología del cine, economía política del cine-, pero 
es ante todo una reflexión desde la antropología y la historia del cine, no tanto del cine o sobre el cine — sobre esto sí hay sendos tratados-, sino de todo aquello que lo rodea, que lo hace posible o está detrás, debajo, por encima, antes y después, y más allá del acto de ver una película en la pantalla. Para Ana Rosas, ir al cine es un hecho social total, y al estudiarlo a profundidad en todas sus facetas e implicaciones llegamos a entender muchos otros fenómenos y aspectos característicos de nuestra cultura y sociedad contemporáneas. La autora demuestra con habilidad que el consumo cultural, en particular el hecho de ir al cine, representa una forma de estar juntos, genera sociabilidad, produce y reproduce vínculos interpersonales e interculturales.

La antropología y la historia del cine raras veces se habían adentrado con tanta seriedad en los fenómenos sociales y culturales adjuntos o adyacentes al cine mismo. La historia del cine no puede ser más un mero recuento de películas, corrientes y directores; debe incorporar de ahora en adelante la historia de ir al cine. Como este libro demuestra, una antropología del cine debe contemplar una reflexión integral en torno a los diversos mundos y culturas del cine, y observar al mismo tiempo las tendencias globales y las particularidades locales que lo enmarcan y configuran. Ana Rosas lo logra a partir de una labor historiográfica y etnográfica ejemplar sobre las viejas y nuevas formas de ser espectador, público, cinéfilo, o bien gestor, programador, exhibidor, y una aguda reflexión sobre sus transformaciones y significados recientes. Por medio de la revisión de momentos históricos, desde la llegada del cine a México, la Revolución, la Época de Oro, la era de la crisis y la resistencia contracultural, hasta los panoramas actuales y escenarios emergentes, se da testimonio de una variedad de experiencias y fenómenos en torno al cine, en una multiplicidad de espacios y modalidades de proyección: las carpas de barrio, los autocinemas, los palacios cinematográficos de antaño, las salas de cine multiplex en centros comerciales, los cineclubes, los festivales, las proyecciones al aire libre, hasta las nuevas formas de consumo digital — doméstico, por demanda, móvil— por medio de internet.

Para decirlo de manera contundente, en nuestro país no se habían estudiado los públicos de cine con la atención, elocuencia y agudeza con que lo hace Ana Rosas en este libro. Desde el comienzo, establece los orígenes y problemas conceptuales de la categoría de público o públicos, en plural. Reconoce la complejidad de esta categoría, esboza sus múltiples dimensiones, la plantea como una noción que nunca puede entenderse de una forma unívoca o definitiva, sino siempre cambiante. A los públicos de cine nunca debemos darlos por hecho, por ello estudiarlos es una tarea permanente, para tratar de comprender sus facetas, transformaciones, nuevas prácticas, imaginarios y afectos, su situación económica, política, social, geográfica, laboral, etc. Cito: "los públicos no nacen como tales, se forman y se transforman permanentemente" (pp. 40-41). En este sentido, este libro atiende un gran hueco que había en nuestras aproximaciones al cine. Sin pretender llenar el vacío, funda un terreno fértil para futuras investigaciones, abre brecha, delimita el campo, sienta las bases, traza los retos y los alcances del estudio de los públicos de cine en nuestro país.

A lo largo de esta exploración, Ana Rosas echa mano de numerosas y diversas fuentes y recursos de investigación: libros teóricos, acervos históricos, hemerografía, fuentes literarias y cinematográficas, y desde luego acude a su propia experiencia. Por ejemplo, en esta investigación juegan un papel muy importante los datos duros, números, estadísticas, censos, información cuantitativa e indicadores de la escala macrosocial. Por otro lado, no se descuidan los aspectos cualitativos y subjetivos del cine, del fenómeno cinematográfico individual. Queda claro que el cine es una forma de experiencia subjetiva 


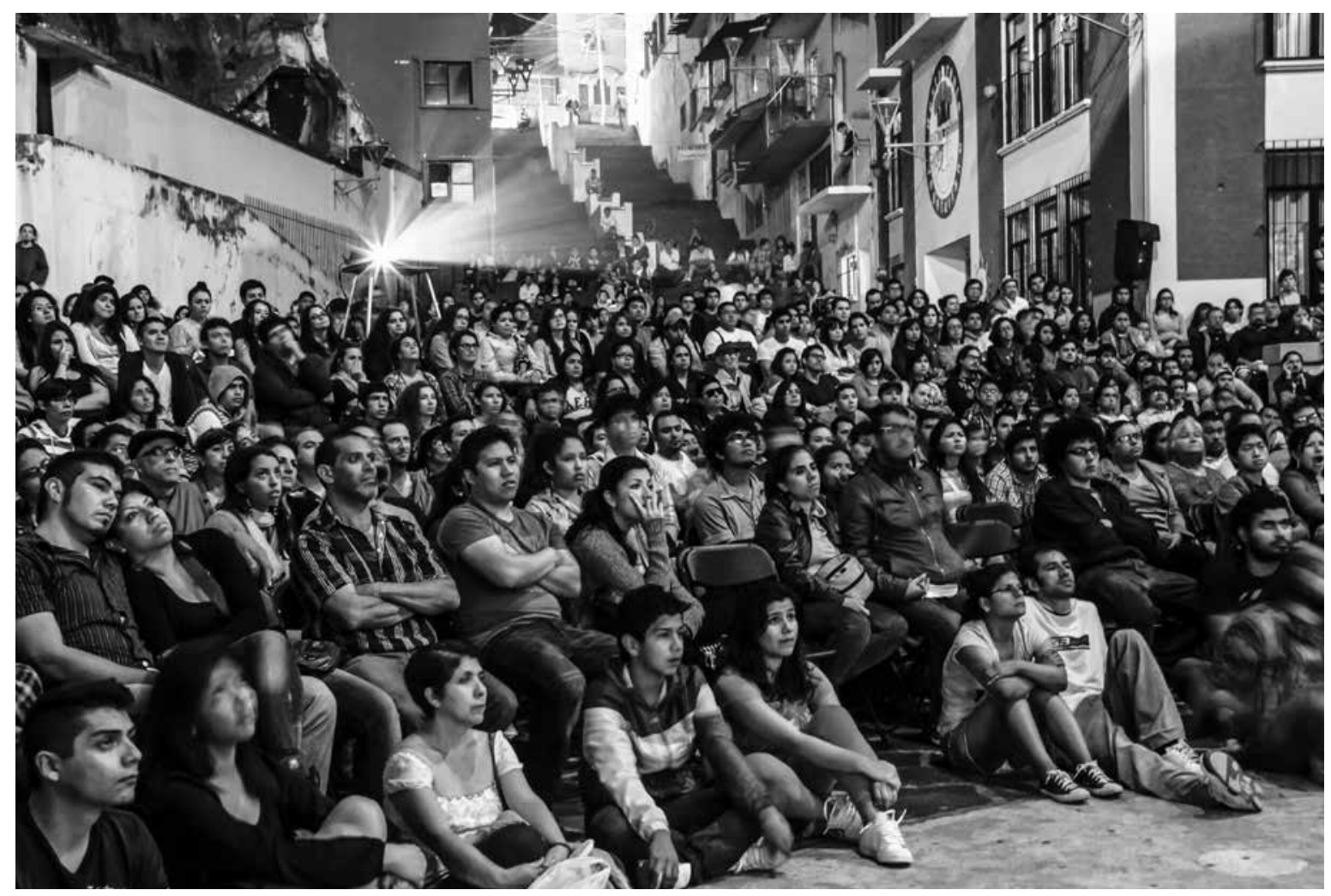

Delia Martínez/Ambulante, A. C. Función del documental Marley durante la Gira de Documentales Ambulante. Plazoleta de Xallitic, Xalapa, Veracruz, 10 de marzo de 2013.

muy poderosa y significativa. El libro nos invita a volver a la vivencia primordial, a la materialidad de los cuerpos, a la parte sensible, a la espacialidad inherente en la acción de ir al cine.

Además, pone de relieve la dimensión política del hecho de ir al cine. Ir al cine, de alguna manera, es también un acto político. Aquí se sistematiza la información dispersa para esbozar un panorama elocuente de la situación del cine nacional. Su lectura brinda claves y elementos para analizar temas cruciales, como el de las políticas públicas relacionadas con la industria del cine en la coyuntura actual. A pesar del éxito del cine mexicano en el gusto extranjero y la crítica internacional, y de manera independiente del incremento de la producción y la proliferación de salas comerciales, nuestro cine sigue siendo rehén de un control centralizado y monopólico. No hay suficiente diversidad de oferta, las condiciones de competencia son totalmente asimétricas, no hay un acceso a la cultura equitativo para todos, predominan una profunda desigualdad, la invisibilidad de buena parte de la producción y la imposibilidad de muchos de convertirse en públicos de cine.

Ante el crecimiento de las industrias creativas y el repliegue del gobierno en este terreno, hacen falta acciones más decididas y mejores leyes contra las prácticas monopólicas de las grandes empresas transnacionales de la distribución y la exhibición de contenidos audiovisuales y contra las políticas de acaparamiento del cine de Hollywood frente a otros cines. ¿Qué acciones gubernamentales serían deseables y 
necesarias para estimular el cine en el México del siglo Xxi? Ana Rosas recomienda, de entrada, no verlo sólo como mercancía ni sólo como arte, no sólo como un producto ni sólo como patrimonio. Subraya que no basta con apoyar la producción y coproducción cinematográfica, pues la distribución y la exhibición siguen siendo el cuello de botella, por no decir la trampa mortal, para el cine mexicano, para el independiente, para todo el cine diferente.

No obstante, Ir al cine también expone muchas iniciativas ciudadanas, como festivales, cineclubes y otros movimientos e instituciones alternativas que representan un contrapeso, que están luchando por revertir estas tendencias y defender una mayor diversidad de la oferta y equidad en el acceso a la experiencia cinematográfica. Deja claro que lo que suceda, lo que hagamos o dejemos de hacer en torno a la industria cinematográfica, resultará ejemplar para hacer valer el derecho a la ciudad, al arte y a la cultura. Sin duda, el cine es un buen termómetro y una caja de resonancia del estado de nuestra sociedad.

Frente a este panorama tan complicado, Ana Rosas mantiene una mirada crítica y realista, pero conserva una postura entusiasta y esperanzadora, que afortunadamente resulta contagiosa y permite augurar un panorama mejor, porque el cine es un vehículo de interculturalidad, un "recurso para que las naciones se conciban a sí mismas, se relacionen con otras y generen entendimiento mutuo" ( $p$. 300), y puede propiciar un mayor entendimiento entre personas y culturas. En palabras del actor Harrison Ford, Ana Rosas nos recuerda que "las salas de cine nos hacen mejores personas", y contribuyen al "arte de vivir juntos", parafraseando a Jérôme Monnet (p. 298).

En suma, ir al cine no es lo mismo que ver una película. Ver una película es sólo una pequeña parte de ir al cine. Hay mucho más, más allá del acto de mirar imágenes en una pantalla. El mundo del cine constituye un espacio de posibilidades, un sitio de encuentro y experimentación con alternativas sociales y culturales. De todo ese universo inmenso y complejo es de lo que trata el libro de Ana Rosas, de un mundo incesante y fascinante, que nunca dejará de sorprendernos. Es un libro que cualquier amante o estudioso del cine no debe dejar de leer. $\mathbf{D}$ 